\title{
Działalność Sekcji Nauk Biblijnych KUL w roku akademickim 2019/2020
}

Academic Activity of the Institute of Biblical Studies CUL in the Year 2019/2020

\author{
TOMASZ BARTŁOMIEJ BĄK \\ Katolicki Uniwersytet Lubelski Jana Pawła II \\ e-mail: tomciobak@gmail.com \\ ORCID: 0000-0003-0328-0282
}

\section{Sprawy personalne}

W roku akademickim 2019/2020 Sekcja Nauk Biblijnych KUL działała w ramach czterech katedr:

\section{Katedra Egzegezy Ksiąg Historycznych, Prorockich i Sapiencjalnych}

Kierownik - ks. dr hab. Dariusz Dziadosz, prof. KUL

Pracownicy:

- ks. dr hab. Andrzej Piwowar

- ks. dr Krzysztof Napora SCJ

- ks. dr Arnold Zawadzki

W roku akademickim 2019/2020 na etacie naukowym w Katedrze Egzegezy Ksiąg Historycznych, Prorockichi Sapiencjalnych zatrudniony został ks. dr Daniel Prokop z diecezji tarnowskiej. 25 maja 2019 r. obronił doktorat The Pillars of the First Temple (1 Kgs 7,15-22). A Study in Ancient Near Eastern, Biblical, Archaelogical and Icongraphic Perspective w Papieskim Instytucie Biblijnym w Rzymie. Promotorem pracy był prof. Peter Dubovsky SJ. 


\section{Katedra Egzegezy Ewangelii i Pism Apostolskich}

Kierownik - dr hab. Krzysztof Mielcarek, prof. KUL

Pracownicy:

- ks. prof. dr hab. Stefan Szymik

- ks. dr hab. Adam Kubiś

\section{Katedra Filologii Biblijnej i Literatury Międzytestamentalnej}

Kierownik - ks. prof. dr hab. Mirosław Stanisław Wróbel

Pracownicy:

- ks. dr hab. Henryk Drawnel, prof. KUL

- ks. dr Tomasz Bąk

\section{Katedra Teologii Biblijnej i Proforystyki}

Kierownik - ks. prof. dr hab. Henryk Witczyk

Pracownicy:

- ks. dr hab. Marcin Kowalski

- ks. dr Marcin Zieliński

\section{Ważniejsze wydarzenia naukowe i organizacyjne}

W dniach 30 września - 4 października 2019 r. pięciu doktorantów Sekcji Nauk Biblijnych KUL (SNB KUL): ks. Krystian Malec, ks. Michał Powęska, o. Tomasz Gali OMI, o. Andrzej Cekiera OCD oraz o. Jacek Pietrzak OP, uczestniczyło w warsztatach z translatoryki tekstów biblijnych "Translating the Bible as Literature: Translating Narrative and Rhetorical Discourse”. Warsztaty szkoleniowe zostały zorganizowane zostały przez NIDA Institute - prestiżowy amerykański ośrodek badań nad Biblią - i odbyły się na Papieskim Uniwersytecie Urbaniana w Rzymie dzięki uprzejmości ks. prof. Andrzeja Gieniusza CR. Wśród prowadzących zajęcia byli m.in. prof. Philip Towner, prof. Lénart de Regt oraz prof. Dan Fitzgerald z zespołu NIDA.

Doktoranci mogli spotkać się także z papieżem Franciszkiem, który w krótkiej rozmowie z uczestnikami seminarium wyraził swoje zainteresowanie tłumaczeniami Pisma Świętego i pobłogosławił wszystkim w ich pracy naukowej. 
W ramach współpracy między SNB KUL a Papieskim Uniwersytetem Urbaniana w Rzymie wykłady dla studentów papieskiej uczelni prowadził $\mathrm{w}$ tym roku ks. dr Arnold Zawadzki. Dwutygodniowy kurs (7-18 października 2019 r.) nosił tytuł: „Prorocy pośrednikami przymierza” („I profeti come mediatori dell'alleanza"). Wykłady były prowadzone w języku włoskim.

4 listopada 2019 r. $w$ auli Centrum Transferu Wiedzy KUL odbyła się promocja trzeciego tomu serii Biblia Aramejska, zawierającego Księgę Kapłańską. Tom został opracowany przez ks. prof. dra hab. Antoniego Troninę, który w tym roku przeżywał również jubileusz 50-lecia kapłaństwa. Wśród prelegentów obecny był dostojny Jubilat, a także rabin Symcha Keller, ks. prof. dr hab. Antoni Paciorek, ks. dr Mariusz Szmajdziński i ks. prof. dr hab. Mirosław Wróbel.

20 listopada 2019 r. miał miejsce wykład p. prof. dr hab. Márii Kardis z Uniwersytetu Preszowskiego w Preszowie (Słowacja), która gościła na naszej uczelni w ramach programu Erasmus. Wykład nosił tytuł „Źródła apokaliptyki żydowskiej okresu Drugiej Świątyni”.

20 grudnia 2019 r. czasopisma naukowe The Biblical Annals i Verbum Vitae, prowadzone przez SNB KUL, decyzją Ministerstwa Nauki i Szkolnictwa Wyższego otrzymały wyższą punktację, wynoszącą aktualnie 70 punktów.

W dniu 26 kwietnia 2020 r. rozpoczął się Tydzień Biblijny, przeżywany pod hasłem „Kto we Mnie wierzy, będzie spożywał Chleb życia wiecznego" (por. J 6,35-36), oraz IV Narodowe Czytanie Pisma Świętego „Misterium Słowa, które stało się Chlebem życia".

Patronat honorowy nad IV Narodowym Czytaniem Pisma Świętego sprawował przewodniczący Konferencji Episkopatu Polski ks. abp Stanisław Gądecki oraz Prezes Rady Ministrów Rzeczypospolitej Polskiej, p. Mateusz Morawiecki. Uroczysta celebracja pod przewodnictwem ks. abpa Marka Jędraszewskiego, rozpoczynająca Narodowe Czytanie Pisma Świętego, miała miejsce w Sanktuarium Miłosierdzia Bożego w Łagiewnikach. W tym roku w sposób szczególny zachęcano do lektury i medytacji Ewangelii według św. Mateusza oraz Księgi Syracha. W organizację tych wydarzeń byli bezpośrednio zaangażowani pracownicy SNB KUL: ks. prof. dr hab. Henryk Witczyk (przewodniczący Dzieła Biblijnego), ks. dr Marcin Zieliński (zastępca przewodniczącego) oraz moderatorzy: ks. prof. dr hab. Mirosław Wróbel i ks. dr hab. Marcin Kowalski.

W dniu 1 czerwca 2020 r. odbyła się w formie on-line obrona pracy licencjackiej o. mgr. Andrzeja Cekiery OCD: Reinterpretacja postaci Melchizedeka w 11QMelch (11Q13), napisanej w Katedrze Filologii Biblijnej i Literatury Międzytestamentalnej pod kierunkiem ks. dra hab. Henryka Drawnela SDB, prof. KUL. Obrona zakończyła się uzyskaniem oceny bardzo dobrej z wyróżnieniem.

W tym samym dniu, również w formie on-line, odbył się egzamin licencjacki o. mgr. Andrzeja Cekiery OCD oraz ks. mgr. Tomasza Gali OMI. Komisji egzaminacyjnej przewodniczył ks. prof. dr hab. Mirosław S. Wróbel. 
W dniu 9 czerwca 2020 r. Słowacka Rada Agencji Akredytacyjnej Szkolnictwa Wyższego zatwierdziła ks. prof. dra hab. Mirosława Wróbla, kierownika SNB KUL, na członka-recenzenta Słowackiej Rady Agencji Akredytacyjnej Szkolnictwa Wyższego (SAAVS).

22 czerwca 2020 r. na Katolickim Uniwersytecie Lubelskim Jana Pawła II odbyły się dwie publiczne obrony rozpraw doktorskich:

- ks. Marcina Biegasa: „Moje ręce uczynity flet i moje palce cytrę” (Ps 151,4). Obraz Dawida w Zwoju Psalmów (11QPsa) z Qumran. Promotorem rozprawy był ks. dr hab. Henryk Drawnel SDB, prof. KUL;

- $\quad$ ks. Michała Zybały: Strategia ewangelizacji Apostoła Narodów na podstawie 1Kor 9,1-27. Studium egzegetyczno-teologiczne. Promotorem rozprawy był ks. prof. dr hab. Henryk Witczyk.

29 czerwca 2020 r. Rada Instytutu Nauk Teologicznych KUL wybrała ks. prof. dra hab. Mirosława S. Wróbla, kierownika SNB KUL, na przedstawiciela dyscypliny Nauki Teologiczne do Senatu KUL.

W dniu 29 czerwca 2020 r. Rada Instytutu Nauk Teologicznych KUL wybrała p. dra hab. Krzysztofa Mielcarka, prof. KUL do Rady Szkoły Doktorskiej KUL.

W dniu 15 lipca 2020 r. Walne Zebranie pracowników SNB KUL powołało do życia Stowarzyszenie na rzecz Wspierania Biblistyki „Verbum Sacrum” oraz wybrało Zarząd w składzie: ks. prof. dr hab. Mirosław S. Wróbel (prezes), ks. dr hab. Adam Kubiś (zastępca prezesa), ks. prof. dr hab. Stefan Szymik (sekretarz), ks. dr Krzysztof Napora (skarbnik).

Podczas 386. Zebrania Plenarnego Konferencji Episkopatu Polski, odbywającego się w dniach 27-29 sierpnia 2020 r., ks. prof. dr hab. Mirosław S. Wróbel, kierownik SNB KUL, został wybrany na konsultora Komisji Nauki Wiary Konferencji Episkopatu Polski.

21 września 2020 r. na Katolickim Uniwersytecie Lubelskim Jana Pawła II w trybie stacjonarnym i w łączności on-line z jednym z recenzentów odbyły się dwie publiczne obrony rozpraw doktorskich:

- p. Michała Klukowskiego: 4QMMT - „Niektóre uczynki Prawa”. Rekonstrukcja tekstu - tlumaczenie - komentarz. Promotorem rozprawy był ks. dr hab. Henryk Drawnel SDB, prof. KUL.

- $\quad$ ks. Mateusza Wyrzykowskiego: Reinterpretacja Ksiegi Kapłańskiej 18,5 i Księgi Powtórzonego Prawa 30,11-14 w Liście do Rzymian 10,4-8. Analiza intertekstualna. Promotorem rozprawy był ks. prof. dr hab. Mirosław S. Wróbel.

W dniu 25 września 2020 r. ks. prof. dr hab. Mirosław Kalinowski, Rektor KUL powołał ks. prof. dra hab. Mirosława S. Wróbla na kierownika SNB KUL na okres od 1 października 2020 r. do 30 września 2024 r. 


\title{
III. Sympozjum naukowe organizowane w Sekcji Nauk Biblijnych KUL
}

\author{
XV Międzynarodowe Jesienne Dni Biblijne: \\ "Signs, Wonders and Mighty Works. \\ God's Activity in the History of Salvation" \\ (,Znaki, cuda i przejawy mocy. Działania Boga w historii \\ zbawienia"), KUL, 23-24 października 2019 r.
}

Tematyka wystąpień sympozjalnych XV Międzynarodowych Jesiennych Dni Biblijnych nawiązywała do fenomenów i przejawów mocy Boga opowiadanych w Biblii i literaturze pozabiblijnej. W szerszej perspektywie mówiono również o historycznych, antropologiczno-kulturowych i teologicznych aspektach starożytnych tekstów dotyczących cudów opisywanych w Biblii Hebrajskiej, Septuagincie, Nowym Testamencie i tekstach antyku chrześcijańskiego.

Konferencję otworzył ks. prof. dr hab. Sławomir Nowosad, dziekan Wydziału Teologii KUL, a pierwszą sesję specjalną poprowadził ks. prof. dr hab. Mirosław S. Wróbel, dyrektor SNB KUL. W ramach sesji wystąpili uczeni z Wielkiej Brytanii i Stanów Zjednoczonych, należący do uznanych specjalistów w podjętej tematyce. Prof. Richard J. Bauckham z Ridley Hall w Cambridge poruszył temat naocznych świadków cudów Jezusa w Ewangelii Marka, o. Anthony Giambrone OP z École biblique z Jerozolimy przedstawił zagadnienie świadectw na temat uzdrowień w świeckie grecko-rzymskim, a prof. Graham H. Twelftree z London School of Theology zajął się kwestią tożsamości Jezusa jako cudotwórcy ( $m a-$ gician).

Szczegółowy program Sympozjum przedstawiał się następująco:

Środa, 23 października

Sesja I

- Richard J. Bauckham (Ridley Hall, Cambridge, Wielka Brytania) „Eyewitnesses and Miracles in the Gospel of Mark".

- Anthony Giambrone (École biblique et archéologique française de Jérusalem) „Memorializing Miracles in the Greco-Roman World of the Gospels”.

- Graham H. Twelftree (London School of Theology, Wielka Brytania) Sesja II „Jesus the Magician?”.

- Ibolya Balla (Pápa Reformed Theological Seminary, Węgry) „Faithful God and Resilient Prophet: The Role of God's Mighty Acts in the Book of Joel". 
- Vincent Chukwuma Onwukwe (KU Leuven, Belgia) „A Son in His Old Age: Reading Genesis 16 and 21:1-21 in Light of the Search for Progeny Sesja III in the Igbo (Nigerian) Socio-Cultural Context".

- Nikos Skuras (Archidiecezja Gdańska, Polska) „The Change in Peter's Mentality Recorded in Acts 10 as an Example of One of God's Key Works in the History of Salvation".

- Jaap Doedens (Pápa Reformed Theological Seminary, Węgry) „The Things That Mark an Apostle: Paul's Signs, Wonders, and Miracles".

- Olubiyi Adeniyi Adewale (National Open University of Nigeria) „An Afro-Sociological Reading of Lukan Miracles”.

Czwartek, 24 października

Sesja IV

- Andrea Antenan Peecher (University of Notre Dame, Stany Zjednoczone) „Memorializing an Eschatological Sign: Cyril's Letter to Constantius II as a Liturgical Source".

- Abraham Boateng (Goethe University, Frankfurt am Main, Niemcy) „Fact, Fiction and Friction: New Testament Miracle Stories in Contemporary Africa".

- Marina Nikolaevna Pasichnik (University of Auckland, Nowa Zelandia) "The Descent of Christ into Hell in Russian Icons".

Sesja V (w języku polskim)

- Marek Ireneusz Baraniak (Uniwersytet Warszawski, Polska) „Idea 'proroka jak Mojżesz' (Pwt 18,15.18) w historii deuteronomistycznej”.

- Andrzej Lukasz Jędrzejczak (Uniwersytet Adama Mickiewicza, Poznań, Polska) „Nadzwyczajne zjawiska astronomiczne a obecność Boga. Katastroficzne wizje Protolzajasza w perspektywie teologii biblijnej”.

- Agata Sowińska (Uniwersytet Śląski, Katowice, Polska) „Magnum Miraculum est homo...': Fenomen 'człowieka-cudu' w filozoficzno-religijnej literaturze hermetycznej pierwszych wieków naszej ery - ujęcie retoryczne".

Ze względu na panującą pandemię koronawirusa nie mogło się odbyć Wiosenne Sympozjum Biblijne, które miało być poświęcone tematowi homoseksualizmu w Biblii. Planowany tytuł sympozjum to „Relacje homoseksualne a zamysı Stwórcy wobec mężczyzny i kobiety". Referaty naświetlające kontekst tej problematyki w starożytnych kulturach oraz analizujące wybrane teksty ze Starego i Nowego Testamentu oraz z pism Ojców Kościoła zostały przeniesione na późniejszy czas. 


\section{Działalność naukowo-dydaktyczna pracowników Sekcji Nauk Biblijnych KUL}

Prezentację działalności naukowo-dydaktycznej rozpoczyna osoba kierownika SNB KUL. W dalszej kolejności przyjęty został porządek alfabetyczny. Pod hasłem „Działalność dydaktyczna poza KUL” należy rozumieć wykłady wykraczające poza obowiązkowe zajęcia prowadzone przez pracowników SNB KUL.

\section{Kierownik Sekcji Nauk Biblijnych KUL ks. prof. dr hab. Mirosław Stanisław Wróbel}

\section{Książki pod redakcją}

1. Grzegorz Pawłowski (Jakub Hersz Griner), Ocaleni z Zagłady (Lublin: Gaudium 2019).

2. Antoni Tronina, Targum Neofiti 1. Księga Kapłańska. Tekst aramejskiprzekład, aparat krytyczny - przypisy (Biblia Aramejska 3; Lublin: Gaudium 2019).

3. Hugolin Langkammer, Księga Syracha. Wstęp, przektad z oryginatu, komentarz, ekskursy (Pismo Święte Starego Testamentu 8/5; Poznań: Pallottinum 2020).

4. Grzegorz Pawłowski (Jakub Hersz Griner), Mesjasz świattem i moca w drodze do nieba (Lublin: Gaudium 2020).

\section{Artykuły naukowe}

1. „Biblical Studies in Poland in the Context of Current Tendencies”, The Biblical Annals 9/4 (2019) 771-830.

2. „Institute of Biblical Studies”, One Hundred Years of Theology at the John Paul II Catholic University of Lublin (Lublin: Wydawnictwo KUL 2019) 29-46.

3. „Współczesne zasady interpretacji Biblii w Kościele”, Biblia i bibliodrama $w$ nowej ewangelizacji (red. M. Kowalczyk - B. Chrudzimska) (Warszawa: Wydawnictwo Naukowe UKSW 2020) 29-39.

4. „The Eschatological Spirituality of 'the Sons of Light' in Qumran”, Verbum Vitae 37/2 (2020) 347-363. 


\section{Artykuły popularnonaukowe}

1. „Od Biblii aramejskiej i Septuaginty do Wulgaty i Biblii Tysiąclecia”, Przegląd Uniwersytecki 6(182) (2019) 26-27.

2. „Pan Jezus zdjęty z krzyża”, Apostoł Miłosierdzia Bożego 1(105) (2020) 40-41.

3. „Księga Habakuka - nazwa, treść i orędzie teologiczne”, Krąg Biblijny 41 (2020) 121-124.

4. „Boża sprawiedliwość i miłosierdzie”, Krag Biblijny 41 (2020) 125-129.

5. „Grób”, Apostoł Miłosierdzia Bożego 2(106) (2020) 52-53.

6. „Księga Sofoniasza - nazwa, treść i orędzie teologiczne”, Krag Biblijny 42 (2020) 111-114.

7. „Dzień Pański w orędziu proroka Sofoniasza”, Krąg Biblijny 42 (2020) $115-119$.

8. „Zmartwychwstanie”, Apostot Miłosierdzia Bożego 3(107) (2020) 62-63.

9. „Tajemnica Jezusa w życiu św. Piotra jako wzór wiary Kościoła”, Przegląd Biblijny 12 (2020) 97-102.

10. „Księga Aggeusza - nazwa, treść i orędzie teologiczne”, Krą Biblijny 43 (2020) 139-142.

11. „Świątynia jerozolimska w orędziu proroka Aggeusza”, Krąg Biblijny 43 (2020) 143-147.

12. „Wniebowstąpienie Jezusa”, Apostoł Miłosierdzia Bożego 4(108) (2020) $58-59$.

\section{Sympozja}

1. XV Międzynarodowe Jesienne Dni Biblijne: „Signs, Wonders and Mighty Works. God's Activity in the History of Salvation". Organizacja, otwarcie i zakończenie Sympozjum (KUL, Lublin, 23-24.10.2019).

2. Promocja trzeciego tomu Biblii Aramejskiej: Targum Neofiti 1. Księga Kapłańska. Udział w panelu dyskusyjnym (KUL, Lublin, 4.11.2019).

3. Referat: „Świętość w nauczaniu Jezusa i pierwotnego Kościoła”. Instytut Kultury Europejskiej, XXIII Ogólnopolski Dzień Judaizmu (Gniezno, 16-17.01.2020).

4. Referat: „Znaczenie Biblii Aramejskiej dla lepszego rozumienia Starego i Nowego Testamentu”, Dni Kultury Chrześcijańskiej (Chełm, 28.09.2020).

\section{Szkolenia i staże}

1. Udział w warsztatach naukowych i spotkaniu tłumaczy 6. wydania Biblii Tysiąclecia (Papieski Uniwersytet Urbaniana, Watykan, 23-26.09.2019). 
2. Kwerenda naukowa (Seton Hall University, Newark, USA, 14-28.12.2019).

3. Kwerenda naukowa (Uniwersytet Betlejem, Palestyna, 3-13.02.2020).

4. Realizacja grantu RID: „Targumy między Starym a Nowym Testamentem”.

5. Realizacja grantu RID: „Wstęp ogólny do Pisma Świętego”.

\section{Promocja pracy doktorskiej}

Ks. Mateusz Wyrzykowski, Reinterpretacja Księgi Kapłańskiej 18,5 i Księgi Powtórzonego Prawa 30,11-14 w Liście do Rzymian 10,4-8. Analiza intertekstualna (Lublin 2020).

\section{Przewodniczenie Komisjom Doktorskim}

Przewodniczenie komisjom miało miejsce podczas następujących obron:

1. Ks. Marcin Biegas, „Moje ręce uczynity flet i moje palce cytrę” (Ps 151,4). Obraz Dawida w Zwoju Psalmów (11QPsa) z Qumran. Promotorem rozprawy był ks. dr hab. Henryk Drawnel SDB, prof. KUL (obrona: 22.06.2020);

2. Ks. Michał Zybała, Strategia ewangelizacji Apostoła Narodów na podstawie 1Kor 9,1-27. Studium egzegetyczno-teologiczne. Promotorem rozprawy był ks. prof. dr hab. Henryk Witczyk (obrona: 22.06.2020);

3. Michał Klukowski, 4QMMT - „Niektóre uczynki Prawa”. Rekonstrukcja tekstu - tlumaczenie - komentarz. Promotorem rozprawy był ks. dr hab. Henryk Drawnel SDB, prof. KUL (obrona: 21.09.2020).

\section{Recenzje}

1. Superrecenzja profesorska o nadanie ks. dr. hab. Andrzejowi Najdzie tytułu profesora $\mathrm{w}$ dziedzinie nauk teologicznych na podstawie dorobku i rozprawy profesorskiej: Paradygmaty życia rodzinnego w Ewangelii wg św. Łukasza (Warszawa: Wydawnictwo Naukowe UKSW 2019).

2. Recenzja pracy doktorskiej: Ireneusz Świątek, Pieśń o winnicy (Iz 5,1-7) i jej reinterpretacja w Ewangeliach synoptycznych (UKSW; Warszawa 2020).

3. Recenzja pracy licencjackiej: o. Andrzej Paweł Cekiera OCD, Reinterpretacja postaci Melchizedeka w 11QMelch (11Q13) (KUL; Lublin 2020).

\section{Recenzje wydawnicze książek}

1. M. Kicka, Eliasz, Elizeusz, Gechazi. Medytacje biblijne (Poznań: Monumen 2020).

2. K. Wojciechowska - M. Rosik, Oczekując miłosierdzia. Komentarz strukturalny do Listu św. Judy (Warszawa: Wydawnictwo Naukowe Chrześcijańskiej Akademii Teologicznej 2020). 
3. E. Leoni (red. wyd. hebrajskiego) - M. K. Frąckiewicz - M. Reczko (red. wyd. polskiego), Księga pamięci gminy żydowskiej w Ciechanowcu (Łomża: Łomżyńskie Towarzystwo Naukowe im. Wagów 2020).

\section{Działalność dydaktyczna poza KUL}

1. Wykłady biblijne prowadzone dla sióstr karmelitanek bosych w Dysie.

2. Zorganizowanie Kursu Formacji Biblijnej KUL 2019-2020. Prowadzenie wykładu monograficznego: „Znaczenie i funkcja Ducha Świętego w Ewangelii św. Jana".

\section{Działania popularyzujące Biblię}

1. Cykl wykładów biblijnych: Eucharystia w Nowym Testamencie (Kaliszany, Ognisko Światła i Miłości, 19-20.10.2019).

2. Cykl wykładów biblijnych: Lectio Divina - Geneza, Znaczenia, Zastosowanie (Otwock, Dom Generalny Sióstr Benedyktynek Misjonarek, 5-12.11.2019).

3. Cykl referatów biblijnych na temat Biblii Aramejskiej oraz udział w promocji trzeciego tomu serii Biblia Aramejska: Targum Neofiti 1. Ksiegga Kapłańska (Niedziela Słowa Bożego, Lublin, Parafia Matki Bożej Różańcowej, 17.11.2019).

4. Cyklu referatów: Apokalipsa św. Jana - Księga Nadziei; Spotkanie Biblijne: „W skarbcu biblijnej mądrości” (Nałęczów, Dom Rekolekcyjny „Promień” Sióstr Służek Maryi Niepokalanej, 10-12.01.2020).

5. Spotkanie z intelektualistami Lublina, wygłoszenie referatu: „Eucharystia - sakrament na życie wieczne" (Lublin, Siostry Misjonarki Szkoły, 22.02.2020).

6. Referat: „List do Kościoła w Efezie” (Ap 2,1-7); Spotkanie biblijne W Blasku i Mocy Słowa Bożego" (Lublin, kościół rektoralny Niepokalanego Poczęcia Najświętszej Maryi Panny, 25.02.2020).

7. Medytacja lectio divina (Mk 4,35-41), Szkoła Słowa Bożego (Lublin, Archikatedra Lubelska, 27.02.2020).

8. Cykl wykładów biblijnych: Biblia Aramejska a Stary Testament, Ognisko Światła i Miłości (Kaliszany, 7-8.03.2020).

9. Cykl wykładów: Znaczenie Nauczania św. Jana Pawła II dla Kościoła XXI Wieku (Lublin, parafia św. Rodziny, 6-9.06.2020).

10. Referat: „Głód eucharystyczny w okresie pandemii” (Lubartów, parafia św. Anny, 11.06.2020).

11. Cykl wykładów: Św. Jan Paweł II - W Służbie Bogu i Człowiekowi (parafia św. Jana Pawła II, 14.06.2020). 


\section{Inne}

1. Organizacja i przewodniczenie Komisji Konkursowej w 24. edycji Ogólnopolskiego Konkursu Biblijnego Katolickiego Stowarzyszenia „Civitas Christiana".

2. Wybór na członka-recenzenta Słowackiej Rady Agencji Akredytacyjnej Szkolnictwa Wyższego (SAAVS) (9.06.2020).

3. Wybór na członka Senatu KUL jako przedstawiciela Instytutu Nauk Teologicznych (29.06.2020).

4. Wybór na prezesa Stowarzyszenia „Verbum Sacrum” (15.07.2020).

5. Wybór na konsultora Komisji Nauki Wiary Konferencji Episkopatu Polski (27.08.2020).

6. Mianowanie na stanowisko kierownika SNB KUL na lata 2020-2024 (25.09.2020).

\section{Ks. dr Tomasz Bąk}

\section{Artykuły naukowe i recenzje}

1. „A Critical Edition and Philological Analysis of the Second Chapter of Deutero-Isaiah (Isa 41) on the Basis of the Coptic Manuscript sa 52 (M 568) in Light of Other Coptic Manuscripts Written in the Sahidic Dialect and the Greek Text of the Septuagint", The Biblical Annals 10/1 (2020) 63-91.

2. „A Critical Edition and Philological Analysis of the Text of Isa 42:1-44:5 on the Basis of the Coptic Manuscript sa 52 (M 568) and Other Coptic Manuscripts Written in the Sahidic Dialect of Coptic and the Greek Text of the Septuagint", The Biblical Annals 10/2 (2020) 225-260.

3. Sprawozdanie: „Działalność Instytutu Nauk Biblijnych KUL w roku akademickim 2018/2019”, The Biblical Annals 10/1 (2020) 155-187.

4. Recenzja książki: Danuta Piekarz, (Nie) święty gniew. Co Biblia mówi o złości? (Kraków: Wydawnictwo WAM 2019), Verbum Vitae 36 (2019) 513-519.

\section{Recenzje wydawnicze}

1. Anonimowa recenzja artykułu naukowego do czasopisma Lódzkie Studia Teologiczne.

2. Anonimowa recenzja artykułu naukowego do czasopisma Verbum Vitae. 


\section{Sympozjum}

Uczestnictwo w radzie naukowej Ogólnopolskiej Interdyscyplinarnej Studencko-Doktoranckiej Konferencji Naukowej: „My, wy, oni. Co i jak starożytni myśleli o sobie i innych?” (KUL, 27.03.2020).

\section{Kwerenda biblioteczna}

Kwerenda naukowa w Bibliotece Papieskiego Uniwersytetu Biblijnego (Biblicum) w Rzymie (28.11 - 12.12.2019).

\section{Promocja prac dyplomowych}

1. Klara Sikora, Paschalne powołanie Piotra do roli Pasterza. Analiza literacka, egzegetyczna i teologiczna J 21,15-19. Podyplomowe Studia Teologiczno-Katechetyczne. Instytut Teologiczno-Pastoralny w Rzeszowie. Wydział Teologii UPJPII w Krakowie (obrona: maj 2020 r.).

2. Barbara Dereń, Relacja między Ojcem, Jezusem i wspólnota walegorii o winnym krzewie. Analiza literacka, egzegetyczna i teologiczna J 15,1-10. Podyplomowe Studia Teologiczno-Katechetyczne. Instytut Teologiczno-Pastoralny w Rzeszowie. Wydział Teologii UPJPII w Krakowie (obrona: maj 2020 r.).

3. Justyna Ślemp, Miłość najdoskonalszym darem Ducha Świętego. Analiza literacka, egzegetyczna i teologiczna „Hymnu o milości” (1Kor 13,1-13). Podyplomowe Studia Teologiczno-Katechetyczne. Instytut Teologiczno-Pastoralny w Rzeszowie. Wydział Teologii UPJPII w Krakowie (obrona: maj 2020 r.).

\section{Działalność dydaktyczna poza KUL}

1. Wykład: Egzegeza Starego Testamentu: Pięcioksiąg; Wyższe Seminarium Duchowne w Rzeszowie (rok IV, semestr I).

2. Wykład: Wprowadzenie do archeologii biblijnej; Wyższe Seminarium Duchowne w Rzeszowie (rok I, semestr I).

3. Wykład: Dzieje Apostolskie i Pisma św. Pawła; Wyższe Seminarium Duchowne w Rzeszowie (rok III, semestr II).

4. Wykład: Wprowadzenie do Starego Testamentu; Podyplomowe Studia Teologiczno-Katechetyczne. Instytut Teologiczno-Pastoralny w Rzeszowie. Wydział Teologii UPJPII w Krakowie 


\section{Ks. dr hab. Henryk Drawnel SDB, prof. KUL}

\section{Monografia}

Qumran Cave 4. The Aramaic Books of Enoch: 4Q201, 4Q202, 4Q204, 4Q205, 4Q206, 4Q207, 4Q212 (In Consultation with Émile Puech) (Oxford: Oxford University Press 2019).

\section{Artykuły naukowe i hasła encyklopedyczne}

1. „Aramaic Levi Document”, T\&T Clark Encyclopedia of Second Temple Judaism (red. Loren T. Stuckenbruck - Daniel M. Gurtner) (London - New York: Clark 2019) I, 106-109.

2. „Astronomy and Astrology”, T\&T Clark Encyclopedia of Second Temple Judaism (red. Loren T. Stuckenbruck - Daniel M. Gurtner) (London - New York: Clark 2019) II, 88-90.

3. „Fallen Angels”, T\&T Clark Encyclopedia of Second Temple Judaism (red. Loren T. Stuckenbruck - Daniel M. Gurtner) (London - New York: Clark 2019) II, 265-267.

4. "The Reception of Genesis 6:1-4 in 1Enoch 6-7", Stone, Tablets, and Scrolls: Periods of the Formation of the Bible (red. P. Dubovský - F. Giuntoli) (ArchB 2; Tübingen: Mohr Siebeck, 2020) 461-483.

5. "Qumran Manuscripts Seventy Years Later”, Sacred Texts and Disparate Interpretations. Qumran Manuscripts Seventy Years Later. Proceedings of the International Conference Held at the John Paul II Catholic University of Lublin, 24-26 October 2017 (red. H. Drawnel) (Studies on the Texts of the Desert of Judah 133; Leiden: Brill 2020) 1-10.

\section{Granty naukowe}

1. Grant RID (= Program grantowy MNiSW, Regionalna Inicjatywa Doskonałości, Filozofia i teologia w kontekście współczesnych przemian nauki przyznany Wydziałowi Filozofii i Teologii KUL) na zorganizowanie międzynarodowej konferencji 21-22 października 2020 r.: ,From the Books of Enoch to Genesis Apocryphon: Aramaic Manuscripts of 1 Enoch in Current Research".

2. Staż naukowy: „Analiza i krytyka manuskryptu nieopublikowanej monografii: Józef T. Milik, Édition et commentaire du Téstament de Levi en araméen (École biblique et archéologique Française de Jérusalem, Jerozolima, Izrael, 06.11-31.12.2019). 
3. Staż naukowy: Analiza i krytyka Pierwszej Księgi Henocha, rozdz. 2-5, na podstawie oryginalnego tekstu aramejskiego poświadczonego w 4Q201 oraz 4Q204 (École biblique et archéologique française de Jérusalem, Jerozolima, Izrael, 19.02-20.04 2020).

4. Grant: MNiSW w ramach programu Doskonała nauka. Tytuł projektu: „Wydanie nieopublikowanej monografii profesora Józefa T. Milika, Le Testament de Levi en araméen" (planowany czas realizacji projektu: od 01.07.2020 do 31.12.2021).

\section{Promocja pracy doktorskiej}

Marcin Biegas, „, Moje ręce uczynity flet i moje palce cytrę” (Ps 151,4). Obraz Dawida w Zwoju Psalmów (11QPsa) z Qumran (obrona: 22.06.2020).

\section{Ks. dr hab. Dariusz Dziadosz, prof. KUL}

\section{Artykuły naukowe}

1. „The Circumcision of the Heart as a Deuteronomic Metaphor of Religious Identity of an Israelite", Biblica et Patristica Thoruniensia 12/2 (2019) 159-189.

2. „Między historią, ideologią i teologią. Pro-Dawidowa lektura tradycji o Saulu w Pierwszej Księdze Kronik", Collectanea Theologica 89/4 (2019) 47-93.

3. „Ideowy i teologiczny podtekst misji »wodza zastępów JHWH« w Joz 5,13-15”, Biblica et Patristica Thoruniensia 13/1 (2020) 25-58.

\section{Rozdziały w podręczniku}

1. Autorstwo rozdziałów i konsultacja biblijna podręcznika do nauki religii: W. Janiga (red.), Bóg poszukuje człowieka. Religia dla V klasy szkoły podstawowej. Karta pracy (Lublin - Przemyśl: Gaudium 2020).

2. Autorstwo rozdziałów i konsultacja biblijna podręcznika do nauki religii: W. Janiga (red.), Bóg poszukuje człowieka. Religia dla V klasy szkoły podstawowej. Poradnik metodyczny (Lublin - Przemyśl: Gaudium 2020).

3. Autorstwo rozdziałów i konsultacja biblijna podręcznika do nauki religii: W. Janiga (red.), Bóg poszukuje człowieka. Religia dla V klasy szkoły podstawowej. Podręcznik (Lublin - Przemyśl: Gaudium 2020). 


\section{Sympozja}

1. Referat naukowy na konferencji krajowej: „Prawo i przymierze Noego w biblijnej relacji o potopie (Rdz 6,1-9,29)", XVI Dni Duchowości Biblijnej: „Dziesięć przykazań Bożych” (Centrum Formacji Duchowej, Kraków, 8-11.11.2019).

2. Referat naukowy na konferencji krajowej: „Prawo patriarchów. Teologiczna analiza cykli tradycji Rdz 11,27-50,26", XVI Dni Duchowości Biblijnej: „Dziesięć przykazań Bożych” (Centrum Formacji Duchowej, Kraków, 8-11.11.2019).

\section{Recenzja pracy doktorskiej}

Kazimierz Pierzchała, Chrystologia starotestamentowa w ujęciu Corpus Paulinum i Listu do Hebrajczyków (Wydział Teologiczny UKSW; Warszawa 2019), napisanej pod kierunkiem ks. prof. dra hab. W. Chrostowskiego.

\section{Ks. dr hab. Marcin Kowalski}

\section{Monografia}

Jutro Niedziela. Rok B (współautor P. Śliwiński) (Kraków: Stacja7 2020).

\section{Artykuły naukowe}

1. „Między darem Bożym a konstruktem społecznym. Wczesnochrześcijańskie rozumienie płciowości na podstawie 1 Kor 11,2-16", Biblica et Patristica Thorunensia 13/1 (2020) 59-104.

2. "The Cognitive Spirit and the Novelty of Paul's Thought in Rom 8,5-6", Biblica 101/1 (2020) 47-68.

\section{Staże, kwerendy i granty}

1. Kwerenda biblioteczna w Adam Cardinal Maida Alumni Library (Orchard Lake, Michigan, USA, wrzesień - grudzień 2019).

2. Uzyskanie grantu wydziałowego na tłumaczenie i publikację dwóch artykułów w wysoko punktowanych czasopismach naukowych (2019-2020).

3. Grant RID. Udział w konferencji międzynarodowej, przygotowanie referatu i publikacja w wysoko punktowanym czasopiśmie naukowym (Preszów, Słowacja 2019) (2019-2020). 
4. Grant z RID. Udział w międzynarodowej konferencji, przygotowanie referatu i publikacji w wysoko punktowanym czasopiśmie (SBL International Meeting, Rome 2019) (2019-2020).

5. Kierowanie zespołem thumaczy 6. wydania Biblii Tysiąclecia, Nowy Testament (2019-2020).

6. Realizacja grantu wspólnie z UPJP II w Krakowie: „Metodologiczna odnowa teologii dogmatycznej”, NCN nr 2017/27/B/HS1/01634. Opracowywane zagadnienie: „Separacja - tak, rozwód - nie. Wyzwania i implikacje płynące z metodologicznego rozwoju nauk biblijnych i teologii systematycznej” (2019-2020).

\section{Recenzje prac magisterskich}

1. A. Piszczek, Życie wedlug Ducha w świetle Rz 8,1-17. Studium egzegetyczno-teologiczne (KUL, 14.05.2020).

2. P. Pikuliński, Boża szkoła wiary wobec grzeszników (Mdr 11,21-12,2). Studium teologiczno-egzegetyczne (KUL, 10.07.2020).

\section{Działalność dydaktyczna poza KUL}

1. Wykłady języku angielskim w Saint Cyril and Methodius Seminary, Orchard Lake, Michigan (wrzesień - grudzień 2019).

2. Wykłady dla sióstr karmelitanek: Pięcioksiąg, Księga Liczb, Księga Powtórzonego Prawa (październik 2019 - marzec 2020).

\section{Działalność popularyzująca Biblię}

1. Wykłady z 1 Listu do Koryntian w ramach Szkoły Dabar (Korynt, 19-26.07.2020).

2. Seria programów telewizyjnych w cyklu Siewcy Słowa (TVP 3 Kielce).

3. Seria programów telewizyjnych w cyklu Telewizyjny Uniwersytet Biblijny (TV Trwam, Toruń).

4. Seria programów radiowych w Radio Maryja, Szukając Słowa Bożego.

5. Seria programów radiowych Słowo na Niedzielę (Poranek rozgłośni katolickich „Siódma 9”, Warszawa).

\section{Inne}

Redakcja czasopisma The Bilical Annals. 


\section{Ks. dr hab. Adam Kubiś}

\section{Artykuły naukowe}

1. „Wytyczne dla autorów INB KUL. IBS KUL Instructions for Contributors”, S. Bazyliński, Wprowadzenie do studium Pisma Świętego. Wydanie drugie poprawione, uzupetnione i poszerzone (Kielce: Jedność 2019) 320-326.

2. "The Hemorrhaging Woman and Jairus' Daughter as Representatives of Israel. An Attempt at the Symbolic Reading of Mark 5:21-43", The Biblical Annals 10/3 (2020) 355-387.

\section{Artykuły popularnonaukowe}

1. „Ostatnia wieczerza i zwoje z Qumran”, Znak Łaski 21/1 (2020) 22-25.

2. „Wiara - dzieło Boga w nas. O rozumieniu ,dzieł Boga” w J 6,29”, Przeglad Biblijny 12 (2020) 100-107.

\section{Sympozja}

Wygłoszony referat: „Theosis - powołani do życia w Duchu Świętym. Perspektywa biblijna”, XII Archidiecezjalny Dzień Biblijny, Centrum Edukacyjno-Formacyjne (Gniezno, 19.10.2019).

\section{Staże i kwerendy}

1. Staż w Sacred Heart Major Seminary w Detroit, Michigan, USA, pod kierunkiem prof. Mary Healy (styczeń - marzec 2020 r.).

2. Kwerenda naukowa w Cardinal Szoka Library, Sacred Heart Major Seminary, Detroit, Michigan, USA (5.02 - 23.03.2020).

3. Kwerenda naukowa w Adam Cardinal Maida Alumni Library, Orchard Lake, Michigan, USA (28.01 - 23.03.2020).

\section{Promocja pracy magisterskiej}

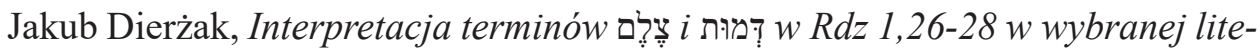
raturze egzegetycznej z lat 1989-2019 (WSD Rzeszów - UPJP2 2020).

\section{Recenzje prac naukowych}

1. Recenzja pracy magisterskiej (Master of Arts): Piotr Kosk, By the End of the New Testament, a Distinct and Useful Concept of Death was Available for 
Subsequent Theological Development (SS. Cyril and Methodius Seminary, Orchard Lake, MI, USA, 20.04.2020).

2. Recenzja pracy magisterskiej: Joanna Stefańska, Modlitwa ucznia Chrystusa wedtug Łk 11,5-13. Studium egzegetyczno-teologiczne (KUL, Lublin, 18.06.2020).

\section{Recenzje wydawnicze książek}

1. Jolanta Judyta Pudełko, Profetyzm w Księdze Syracha (Studia Biblica Lublinensia 21; Lublin: Wydawnictwo KUL 2020).

2. Krzysztof Siwek, Powstat prorok jak ogień. Droga Eliasza (Biblijni Bohaterowie Wiary 1; Warszawa: Wydawnictwo Naukowe Collegium Bobolanum 2020).

\section{Działalność dydaktyczna poza KUL}

1. Visiting Professor w SS. Cyril \& Methodius Seminary w Orchard Lake, MI, USA. Dwa wykłady: Synoptic Gospels and Acts (60 godzin), Johannine Literature and Reveletion (60 godzin) $(28.01-01.05 .2020)$.

2. Wykład: Biblijna historia zbawienia (15 godzin, WSD Rzeszów, semestr zimowy 2019).

3. Wykład: Ewangelie synoptyczne (45 godzin, WSD Rzeszów, semestr zimowy 2019).

4. Seria 5 wykładów na temat greki biblijnej NT (WSD Rzeszów, lipiec 2020).

5. Seria 11 wykładów na temat Ewangelii Jana i 1 Listu św. Jana (3-8.08.2020, IV Letnia Szkoła Biblijna, Hermanice-Ustroń).

\section{Działania popularyzujące Biblię}

1. Organizacja warsztatów archeologiczno-egzegetycznych „Paweł w Koryncie” w ramach projektu „Szkoła Dabar” (18-28.07.2020, Stare Epidauros, Grecja).

2. Organizacja i współprowadzenie warsztatów biblijnych „Korepetycje z listów św. Pawła” (Diecezjalny Dom „Tabor”, Rzeszów, 19-20.09.2020); referat: „Dar języków w NT i historii Kościoła” (19.09.2020).

\section{Audycje radiowe}

1. „Przypadki Abrahama: Biblia, historia, interpretacje” (Polskie Radio Rzeszów, 2.10.2019). 
2. „Czy Bóg kazał Abrahamowi zabić syna?” (Polskie Radio Rzeszów, 9.10.2019).

3. „Co Biblia mówi o śmierci?” (Katolickie Radio Via, Rzeszów, 1.11.2019).

4. „Co Biblia mówi o duszy?” (Katolickie Radio Via, Rzeszów, 2.11.2019).

5. „Betlejem oczami księdza, biblisty, przewodnika” (Katolickie Radio Via, Rzeszów, 25.12.2019).

6. „Rozmnożenie chleba w relacji Ewangelisty Marka jako zapowiedź Eucharystii 1: Jeszcze nie rozumiecie" (Radio Jasna Góra, 12.1.2020).

7. „Rozmnożenie chleba w relacji Ewangelisty Marka jako zapowiedź Eucharystii 2: Kosze ułomków" (Radio Jasna Góra, 20.1.2020).

8. „Jezus, kobieta syrofenicka i Eucharystia 1: Uzdrowieni przez wiarę” (Radio Jasna Góra, 22.03.2020).

9. „Jezus, kobieta syrofenicka i Eucharystia 2: Jedli aż do nasycenia” (Radio Jasna Góra, 26.03.2020).

10. „Czy warto czytać Pismo Święte? Na kanwie Tygodnia Biblijnego” (Radio Via, Rzeszów, kwiecień 2020).

\section{Inne}

Redakcja czasopisma Verbum Vitae.

\section{Dr hab. Krzysztof Mielcarek, prof. KUL}

\section{Artykuł naukowy}

„Maryja w Kościele apostolskim w świetle pism Łukaszowych”, Kościót i Maryja (red. A.A. Napiórkowski) (Kraków: Wydawnictwo UPJP II 2020) 29-49.

\section{Artykuły popularnonaukowe}

1. „Historia zbawienia - Stary Testament. Cz. II/11. Literatura apokaliptyczna”, Krag Biblijny 39 (2019) 109-115.

2. „Historia zbawienia - Nowy Testament. Cz. II/12. Jezus Chrystus - Osoba i dzieło", Krag Biblijny 40 (2019) 151-157.

3. „Historia zbawienia - Nowy Testament. Cz. II/12. Jezus Chrystus - Osoba i dzieło cz. 2", Krag Biblijny 41 (2020) 111-119. 


\section{Sympozja}

1. Wygłoszenie referatu: „Maryja w Kościele apostolskim w świetle pism Łukaszowych", Międzynarodowe sympozjum: Jasnogórska Matka Kościoła (Częstochowa, UPJPII, 24-25.01.2020).

2. Wygłoszenie referatu: „Uświęć nas w prawdzie - Synoptyczna tradycja o Jezusie nauczającym »w prawdzie« (Mk 12,14; Mt 22,16; Łk 20,21)”, I Kongres Biblijny Archidiecezji Przemyskiej (26.10.2019).

\section{Promocja prac magisterskich}

1. Kacper Pawlak, ,Sprzedaj wszystko co masz, rozdaj ubogim (...) i chodź za mna" (Mk 10,21). Ubóstwo jako droga do bycia uczniem Jezusa. Studium egzegetyczno-teologiczne (KUL, obrona: 10.06.2020).

2. Maria Kaszuba, Miłosierdzie wobec bliźniego droga do osiagnięcia życia wiecznego (Łk 10,25-37). Studium egzegetyczno-teologiczne (KUL, obrona: 26.06.2020).

3. Joanna Stefańska, Modlitwa ucznia Chrystusa wedtug Łk 11,5-13. Studium egzegetyczno-teologiczne (KUL, obrona: 18.06.2020).

4. Marcin Rutkowski OP, ,,Walczcie by wejść przez waskie drzwi...” Rozumienie zbawienia $w$ Łk 13,22-30. Studium egzegetyczno-teologiczne (Kraków, UPJPII, 2020).

\section{Recenzja wydawnicza książki}

U. Dudziak (red.), The Great Defenders of Life. Wielcy obrońcy życia (Lublin: Wydawnictwo KUL 2019).

\section{Działalność dydaktyczna poza KUL}

1. Wykład: Ewangelie synoptyczne (48 godzin, Kolegium Filozoficzno-Teologiczne oo. Dominikanów w Krakowie).

2. Wykład: Pięcioksiąg (24 godziny; Kolegium Filozoficzno-Teologiczne oo. Dominikanów w Krakowie).

3. Wykład: Wprowadzenie do Pisma Świętego (10 godzin, Dominikańskie Studium Filozofii i Teologii w Krakowie).

4. Wykład: Pięcioksiąg (12 godzin, Dominikańskie Studium Filozofii i Teologii w Krakowie).

5. Wykład: Wprowadzenie do Pisma Świętego (12 godzin, Studium Dominicanum w Warszawie). 
6. Wykład: Wybrane perykopy z Tory (6 godzin, Studium Dominicanum w Warszawie).

7. Wykład: Wprowadzenie do Pięcioksięgu (16 godzin, Kurs Formacji Biblijnej w Lublinie).

\section{Ks. dr Krzysztof Napora SCJ}

\section{Artykuły naukowe}

1. „Czas w kapłańskim opowiadaniu o stworzeniu: dzień pierwszy (Rdz 1,3-5)”, Verbum Vitae 35 (2019) 7-37.

2. „Jak piękna jest miłość twoja (Pnp 4,10). Piękno w Pieśni nad pieśniami”, Ethos. Kwartalnik Instytutu Jana Pawła II KUL 32/3 (2019) 29-48.

3. „There may yet be hope... (Lam. 3:29). Destruction, Suffering, and Hope in the Book of Lamentations", Ethos. Kwartalnik Instytutu Jana Pawła II KUL 32/4 (2019) 21-43.

\section{Artykuły popularnonaukowe}

1. „Pan pochwalił nieuczciwego rządcę”, Czas Serca 5(162) (2019) 38-39.

2. „Bóg jest Bogiem żywych”, Czas Serca 6(163) (2019) 38-39

3. „Chodźmy także i my, aby razem z Nim umrzeć”, Czas Serca 1(164) (2020) 24-25.

4. „Nie bójcie się”, Czas Serca 2(165) (2020) 24-25.

5. „Jerycho - miasto po drodze...”, Galilea 7 (2019) 5-9.

\section{Sympozjum}

Wygłoszenie referatu: „Lecture de Couronne d'Amour au Sacré-Cœur dans la clé de la Bible” w czasie konferencji międzynarodowej „Couronne d'Amour”. poświęconej dziełu o. Leon J. Dehona (Clairefontaine, 9-11.09.2019).

\section{Recenzja pracy magisterskiej}

Kacper Pawlak, ,Sprzedaj wszystko co masz, rozdaj ubogim (...) i chodź za Mną” (Mk 10,21). Ubóstwo, jako droga do bycia uczniem Jezusa. Studium egzegetyczno-teologiczne (KUL, Lublin, 10.06.2020). 


\section{Działalność dydaktyczna poza KUL}

Wykład: Egzegeza Starego Testamentu (Wyższe Seminarium Misyjnym Księży Sercanów w Stadnikach).

\section{Działania popularyzujące Biblię}

1. Współorganizacja kursów poświęconych postaciom Abrahama i Dawida w ramach Szkoły Biblijnej „Dabar” (Jerozolima, 16-31.08.2019).

2. Cykl comiesięcznych wykładów dla sióstr karmelitanek w Dysie.

3. Audycje radiowe „Szukając Słowa Bożego” (Radio Maryja, Toruń).

4. Udział w konferencji na temat apostolstwa biblijnego na Sri Lance $(27.10-01.11 .2019)$.

5. Nagranie 7 komentarzy do Ewangelii dnia dla Telewizji Trwam (Toruń, czerwiec 2020).

6. Wykłady pastoralne dla Zgromadzenia Sióstr Służebniczek Śląskich na temat biblijnej postaci Mojżesza (30.06 - 6.07.2020).

7. Wykłady pastoralne dla Zgromadzenia Franciszkanek Misjonarek Maryi na temat Psalmu 45 (Łabunie, 7-9.07.2020).

8. Wykłady na temat Księgi Rodzaju oraz spotkania Lectio divina dla uczestników kursu „Na fali wielbienia” (Licheń, 12-17.07.2020).

9. Prowadzenie spotkań Lectio divina w Parafii Dobrego Pasterza w Lublinie oraz postulacie Zgromadzenia Sióstr Franciszkanek Misjonarek Maryi w Dąbrowicy.

\section{Ks. dr hab. Andrzej Piwowar}

\section{Artykuły naukowe}

1. „Znaczenie przymiotnika aíviıৎ w Setpuagincie, pseudoepigrafach Starego Testamentu i Nowym Testamencie w nawiązaniu do interpretacji Wacława Hryniewicza tekstu Mt 25,46", Verbum Vitae 36 (2019) 445-490.

2. „Znaczenie rzeczownika kó $\alpha \sigma ı \varsigma$ w Septuagincie, pseudoepigrafach Starego Testamentu i w Nowym Testamencie w nawiązaniu do interpretacji Wacława Hryniewicza Mt 25,46", Verbum Vitae 36 (2019) 409-443.

3. „Znaczenie i rola Izaaka i Jakuba w historii Izraela według Syracha (Syr 44,22-23)", The Biblical Annals 9/1 (2019) 35-72.

4. „Nowy podręcznik do nauki składni nowotestamentowej greki. Analiza merytoryczno-dydaktyczna", The Biblical Annals 9/3 (2019) 547-567. 
5. „Respect for the Doctor (Sir 38:1-3)”, The Biblical Annals 10/1 (2020) $31-62$.

6. „Biblijne pojmowanie prawdy”, Zamieszkać w Stowie 2 (2020) 89-126.

\section{Granty naukowe}

1. Grant wydziałowy na tłumaczenie i publikację dwóch artykułów w wysoko punktowanych czasopismach naukowych (2019-2020).

2. Grant wydziałowy na opublikowanie monografii naukowej: Analiza sktadniowa greckiego tekstu Ewangelii wedtug św. Marka. I. Mk 1-5.

3. Grant RID. Publikacja monografii naukowej: Analiza sktadniowa greckiego tekstu Ewangelii wedtug św. Marka. II. Mk 6-10.

\section{Recenzje prac magisterskich}

1. Maciej Pawlik, Deuteronomistyczna koncepcja pobytu Izraelitów na wygnaniu. Studium egzegetyczno-teologiczne Jr 29,1-32 (KUL; Lublin 2019).

2. Waldemar Wawrzyszko, Stowo Boże w duchowej i duszpasterskiej formacji kapłana. Studium analityczno-porównawcze wybranych tekstów „Rozmyślań o życiu kapłańskim” św. bpa Józefa Sebastiana Pelczara (KUL; Lublin 2019).

\section{Udział w postępowaniach habilitacyjnych}

1. Recenzent w postępowaniu habilitacyjnym ks. dra Wojciecha Węgrzyniaka (Wydział Teologiczny UPJPII, 2020).

2. Sekretarz komisji ds. habilitacji ks. dra Adama Kubisia (Wydział Teologii KUL, 2019).

\section{Ks. prof. dr hab. Stefan Szymik MSF}

\section{Artykuły i recenzje naukowe}

1. „Wychowanie dzieci w tradycji biblijnej,” Teologia i Moralność 14/2 (2019) $59-72$.

2. „The Corinthian Opponents of the Resurrection in 1 Cor 15:12. The Epicurean Hypothesis Reconsidered", The Biblical Annals 10/3 (2020) 437-456.

3. „«Prawda was wyzwoli» (J 8,32). Prawda i wolność w perspektywie biblijnej," Zamieszkać w Słowie 2 (2020) 167-178. 
4. „Jesus' Intitulation of God as Abba: Its Sources and Impact on the Idea of the Fatherhood of God in the New Testament," Verbum Vitae 38/2 (2020) 485-502.

5. Recenzja książki: R. Bartnicki, Jezus w drodze do śmierci i zmartwychwstania. Komentarz do Ewangelii Marka 8,27-16,20. II. Mk 14,1-16,20 (Warszawa: Instytut Papieża Jana Pawła II 2019), Verbum Vitae 38/2 (2020) 679-681.

\section{Sympozjum}

Wygłoszenie referatu: „Prawda was wyzwoli (J 8,31). Prawda i wolność w perspektywie biblijnej, I Kongres Biblijny Archiprezbiteratu Sanockiego (Strachocina, 5.10.2019).

\section{Szkolenia, kwerendy i granty}

1. Udział w projekcie: „Zintegrowany Program Podnoszenia Kompetencji studentów i pracowników Katolickiego Uniwersytetu Lubelskiego Jana Pawła II”: „Projektowanie i prowadzenie kursów on-line” (60 godzin; platforma Moodle).

2. Kwerenda naukowa w Fachbereichsbibliothek - Theologie, Universitätsbibliothek der Universität Wien (Wiedeń, 11-16.07.2020).

3. Grant RID (= Program grantowy MNiSW, Regionalna Inicjatywa Doskonałości, Filozofia i teologia w kontekście współczesnych przemian nauki przyznany Wydziałowi Filozofii i Teologii KUL) na monografię naukową: Ziemia Przymierza. Geografia i archeologia biblijna w zarysie (Lublin: Wydawnictwo KUL).

\section{Recenzje wydawnicze książek i artykułów}

1. A.R. Sikora, Księga Koheleta. קהלת, Zjęzyka hebrajskiego na język polski $i$ kaszubski przettumaczyt i przypisami opatrzyt o. Adam R. Sikora OFM (Poznań: Wydział Teologiczny UAM 2020).

2. T. Kusz, Ewangelia wedtug św. Łukasza. Wstęp, przektad z oryginatu, komentarz (Biblia - Impulsy; Katowice: Księgarnia św. Jacka).

3. Anonimowe recenzje artykułów naukowych dla czasopism: The Biblical Annals, Ethos, Roczniki Teologiczne (ChAT) i Verbum Vitae. 


\section{Działalność dydaktyczna poza KUL}

1. Wykłady z Nowego Testamentu: Literatura epistolarna (44 godziny; WSD MSF w Kazimierzu Biskupim - oddział Wydziału Teologicznego UAM, Poznań).

2. Wykłady z metodologii biblijnej: Metody interpretacji Pisma Świętego (16 godzin, Kurs Formacji Biblijnej Archidiecezji Lubelskiej).

\section{Ks. prof. dr hab. Henryk Witczyk}

\section{Artykuł naukowy}

„Laudacja na cześć ks. prof. Waldemara Chrostowskiego z okazji nadania honorowego członkostwa w Stowarzyszeniu Biblistów Polskich", Collectanea Theologica 89/3 (2019) 179-192.

\section{Artykuły popularnonaukowe}

1. Bóg i Jezus Chrystus nie błogosławi relacjom homoseksualnym, https:// opoka.org.pl/biblioteka/P/PS/kswitczyk_homoseksualizm.html [dostęp: 15.01.2021].

2. Praktyki homoseksualne w świetle Pisma Świętego, https://www.radiomaryja.pl/polecamy/praktyki-homoseksualne-w-swietle-pisma-swietego/ [dostęp: 15.01.2021].

3. Grzech homoseksualizmu w Piśmie Świętym, https://www.pch24.p1/ks-prof-henryk-witczyk--grzech-homoseksualizmu-w-pismie-swietym,73000,i.html [dostęp: 15.01.2021].

4. Jezus Chrystus a homoseksualizm, https://www.fronda.pl/a/ks-prof-henryk-witczyk-jezus-chrystus-a-homoseksualizm,129570.html [dostęp: 15.01.2021].

5. H. Witczyk - G. Górny, Papieska Komisja Biblijna przedstawia prawdęo homoseksualizmie objawiona w Piśmie Świętym, https://wpolityce.pl/kosciol/ 483826-ks-prof-witczykkomisja-pokazuje-prawde-o-homoseksualizmie [dostęp: 15.01.2021].

\section{Tłumaczenie dokumentu Papieskiej Komisji Biblijnej}

„Czym jest człowiek?” (Ps 8,5).Zarys antropologii biblijnej (Kielce: Jedność 2019). 


\section{Promocja pracy doktorskiej}

Ks. Michał Zybała, Strategia ewangelizacji Apostoła Narodów na podstawie 1Kor 9,1-27. Studium egzegetyczno-teologiczne (Wydział Teologii KUL, obrona 22.06.2020).

\section{Promocja prac magisterskich}

1. Patryk Pikuliński, Strategia ewangelizacji Apostoła Narodów na podstawie 1Kor 9,127. Studium egzegetyczno-teologiczne.

2. Uladzislau Minko, Postawa człowieka wobliczu działania Boga w Koh 3,10-15. Studium egzegetyczno-teologiczne.

\section{Działania popularyzujące Biblię}

Wykłady w Telewizyjnym Uniwersytecie Biblijnym. Katedra Teologii Biblijnej. Wykłady poświęcone Ewangelii według św. Jana (J 4-7).

\section{Inne}

1. Redakcja czasopisma Verbum Vitae.

2. Organizacja pracy Stowarzyszenia Biblistów Polskich - w roli przewodniczącego Zarządu.

3. Organizacja pracy Dzieła Biblijnego im. Jana Pawła II - w roli przewodniczącego Zarządu.

4. Organizacja Pierwszej Niedzieli Słowa Bożego (26.01.2020) (materiały dla Kościoła w Polsce).

5. Organizacja i przygotowanie merytoryczne ogólnopolskiego XII Tygodnia Biblijnego (26.04 - 02.05.2020): redakcja Przegladu Biblijnego. Biuletyn Dzieła Biblijnego: Dwunasty Tydzień Biblijny. Materiały 12 (2020) (Lublin, 2020).

6. Organizacja i przygotowanie ogólnopolskiego IV Narodowego Czytania Pisma Świętego (26.04.2020) (materiały, wywiady w Tvp Info i Tv Trwam, redakcja komentarza w kluczu lectio continua do Ewangelii według św. Mateusza). 


\section{Ks. dr Arnold Zawadzki}

\section{Artykuły naukowe}

1. „Kim jest oblubieniec w przypowieści o dziesięciu pannach (Mt 25,1-13)? Między tradycyjnymi i współczesnymi próbami zrozumienia”, The Biblical Annals 9/2 (2019) 353-396.

2. „Una nuova accezione del verbo עָבָ in Os 10,11bc”, The Biblical Annals 9/3 (2019) 463-480.

3. „E se Osea non fosse esistito davvero...? Il neostoricismo negli studi biblici contemporanei - prospettive e inquietudini”, The Biblical Annals 10/2 (2020) 303-326.

\section{Sympozja}

1. Wygłoszenie referatu: „Czy lektura żydowska Biblii jest potrzebna chrześcijanom”, XXII Ogólnopolski Dzień Judaizmu w Kościele Katolickim (Łódź, 17.01.2020).

2. Wygłoszenie referatu: „Biblijne podstawy nauczania o małżeństwie i rodzinie w adhortacji Amoris laetitia papieża Franciszka", IV Synod Archidiecezji Łódzkiej (2019).

\section{Promocja pracy magisterskiej}

Konrad Sulmirski, Wypetnienie się mesjańskiego proroctwa ST w osobie i misji Jezusa na przykładzie Łk 4,16-30 (Papieski Wydział Teologiczny w Warszawie, Sekcja św. Jana Chrzciciela, maj 2020).

\section{Promocja prac dyplomowych}

1. Lilla Mianowska, Zmartwychwstanie i nowe zrozumienie osoby Jezusa (Papieski Wydział Teologiczny w Warszawie, Sekcja św. Jana Chrzciciela, październik 2019).

2. Hanna Zienkiewicz, Rut - kobieta wierzaca pośród trudów życia (Papieski Wydział Teologiczny w Warszawie, Sekcja św. Jana Chrzciciela, październik 2019).

3. Marta Podel, Sens i wymowa przypowieści o synu marnotrawnym (Papieski Wydział Teologiczny w Warszawie, Sekcja św. Jana Chrzciciela, czerwiec 2020). 


\section{Ks. dr Marcin Zieliński}

\section{Artykuł naukowy}

„Przyszedt mi z pomoca duch madrości (Mdr 7,7). Relacja między starotestamentową mądrością a działaniem Ducha Świętego", Verbum Vitae 37/1 (2020) 35-47.

\section{Recenzja pracy magisterskiej}

Andrzej Piszczek, Życie wedtug Ducha w świetle Rz 8,1-17. Studium egzegetyczno-teologiczne (KUL; Lublin 2020).

\section{Recenzja wydawnicza}

Anonimowa recenzja artykułu naukowego do czasopisma Colectanea Theologica (2020).

\section{Staże, kwerendy i granty}

1. Uzyskanie grantu wydziałowego na thumaczenie i publikację dwóch artykułów w wysoko punktowanych czasopismach naukowych (2019-2020).

2. Uzyskanie grantu RID na udział w konferencji „Imago Dei” na Węgrzech oraz publikację artykułu w publikacji posympozjalnej.

\section{Działalność dydaktyczna poza KUL}

Wykład: Marność i radość w Księdze Koheleta (16 godzin, Kurs Formacji Biblijnej w Lublinie, 2019/2020).

\section{Działania popularyzujące Biblię}

1. Cykl audycji w Telewizyjnym Uniwersytecie Biblijnym TV Trwam oraz konferencji biblijnych w Radiu Maryja: Szukając Słowa Bożego.

2. Organizacja Ogólnopolskiego Tygodnia Biblijnego w roli zastępcy przewodniczącego Dzieła Biblijnego.

3. Organizacja Ogólnopolskiego Narodowego Czytania Pisma Świętego w roli zastępcy przewodniczącego Dzieła Biblijnego.

4. Redakcja strony internetowej Dzieła Biblijnego. 


\section{Inne}

Organizacja Ogólnopolskiego Konkursu Biblijnego dla Kleryków Wyższych Seminariów Duchownych. 
